Arab Univ. J. Agric. Sci., Ain Shams Univ., Cairo, 14(1), 337-347, 2006

\title{
EFFECT OF SPRAYING MAGNESIUM, BORON, ASCORBIC ACID AND VITAMIN B COMPLEX ON YIELD AND FRUIT QUALITY OF “CANINO” APRICOT
}

[22]

\author{
Elham, Z.A. Daood ${ }^{1}$ and M.F.M. Shahin ${ }^{1}$
}

\begin{abstract}
Canino apricot trees received four sprays of magnesium sulphate at $0.5 \%, 1.0 \%$ and 3.0\%, boric acid at $0.2,0.5$ and $1.0 \%$, ascorbic acid at 250, 500 and $1000 \mathrm{ppm}$, Vitamin B complex at 100, 200 and 400 ppm and a combination of the medium concentrations of each substrate were evaluated during 2004 and 2005 seasons. Single or combined application of magnesium, boron, ascorbic acid or vitamin B complex was favourable for improving leaf area, leaf mineral content $(\mathrm{N}, \mathrm{P}, \mathrm{K}$ and $\mathrm{Mg}$ ), yield as well as physical and chemical properties of the fruits compared to untreated trees. The promotion effect was associated with increasing the applied concentrations. Using magnesium, born, ascorbic acid and vitamin B complex, in descending order was very effective in improving growth, nutritional status, fruit quantity and quality. Carrying out four sprays at starting growth, after blooming, after fruit setting and at three weeks later with a combination of $1.0 \%$ magnesium sulphate, $0.5 \%$ boric acid, 500ppm ascorbic acid and 200 p.p.m vitamin B complex suggested to be beneficial in improving growth, nutritional status, yield and fruit quality of "Canino" apricot.
\end{abstract}

Keywords: Apricot, Boron, Ascorbic acid, Yield, Quality

\section{INTRODUCTION}

Improving productivity of "Canino" apricot trees growing under sandy soil could be achieved through supplying the trees with their requirements from nutrients and antioxidants at the optimum concentration.

It is well known that, vitamins act as co-enzymes in a number of enzymes and thus take apart in the regulation of metabolism. Recently, it was suggested that B-vitamins participate in plant growth and development indirectly by enhancing the endogenous levels of various growth factors such as cytokinins and gibberellins (Kodendaramaiah and GopalaRao, 1985). Most B- vitamins are synthesized in leaves and translocated in the phloem. For more than two decades, studies of role of B- vitamins groups in plants have attracted sporadic attention. These studies have indicated that various physiological processes e.g. nutrient uptake, respiration, photosynthesis as well as chlorohyll and protein synthesis depend

1- Pomology Department, National Research Center, Dokki, Giza, Egypt

(Received November 1, 2005)

(Accepted December 21, 2005) 
more or less on the availability of B- vitamins (Samiullah et al 1988).

Vitamins with their antioxidative properties play an important role in plant defense against oxidative stress induced by surfactants and selected pesticides (Orth et al 1993). Application of vitamins was accompanied with enhancing growth and productivity of fruit crops (Oertli 1987; Farag, 1999; Morsy \& EL-Bana, 2000 and Nomier-Safaa, 2000). Nowadays, there is awidespread use of the antioxidants especially ascrobic acid as natural and organic antioxidant compound has an auxinic action. It has synergistic effect on improving growth, flowering, yield and fruit quality of fruit crops (Prusky, 1988; Ahmed et al 1997a, 1998a \& 1998b and Khiamy, 1999).

Canino apricot trees grown under sandy soil suffer from nutrients deficiencies particularly magnesium and boron due to the high fixing rate beside the low soil fertility. The continuous exhaustion due to the growth of the development of fruits can also aggrevate magnesium and boron deficiency symptom. As it is known, the nutritional status of the trees has a striking and important role in controlling fruiting. Application of born (Abd-EL-Aziz, 1994; Mirabdulbaghi, 1996; Wojcik et al 1997; Ahmed et al 1997 and Ahmed \& Morsy, 2001) and Magnesium (Yogaratnam \& Greenham, 1982; Nijjar, 1995; Chekan, 1988 \& 1989; Guo \& Xu, 1998 and Ahmed \& Morsy, 2001).

Therefore, this study aimed to evaluate the role of in magnesium, boron, Bvitamins and ascrobic acid in improving growth, nutritional status, yield and fruit quality of canino apricot trees grown under reclaimed sandy soil.

\section{MATERIAL AND METHODS}

This study was established in 2004 and 2005 seasons on fourty- two Canino apricot trees grown in a private orchard located at Nobareia, EL Behera Governorate. The trees were 10 years old at the start of such study. They were grown in sandy soil and planted at $5 \times 5 \mathrm{~m}$ apart. Trees were similar in growth vigour, regular agricultural practices such as hoeing, drip irrigation, fertilization and pest control management were done as usual to all the investigated apricot trees.

\section{The experiment included the following} fourteen treatments

1- Control (untreated trees).

2- Spraying magnesium sulphate $(9.6 \% \mathrm{Mg})$ at $0.50 \%$.

3- Spraying magnesium sulphate at $1.0 \%$.

4- Spraying magnesium sulphat at $3.0 \%$.

5- Spraying boric acid $(17 \% \mathrm{~B})$ at $0.20 \%$

6- Spraying boric acid at $0.5 \%$.

7- Spraying boric acid at $1.0 \%$.

8- Spraying ascorbic acid at 250 p.p.m

9- Spraying ascorbic acid at 500p.p.m.

10- Spraying ascorbic acid at 1000 p.p.m.

11- Spraying vitamin B complex at 100 p.p.m.

12- Spraying vitamin B complex at 200 p.p. $m$.

13- Spraying vitamin B complex at 400 p.p.m.

14- A combination of $1 \% \mathrm{Mg} \mathrm{SO} 4$, $0.5 \%$ boric acid, 500 p.p. $\mathrm{m}$ ascorbic acid and 200 p.p. m vitamin B complex. 
The all tested treatments were sprayed four times in the same trees

1-One at growth start (1st week of Feb).

2-Twice after blooming (3 rd week of March).

3-Three just after fruit setting (1st week of April).

4-Four at three weeks later (last week of April).

The experiment was designed in a completely randomized blocks with three replicates, each consisted of one tree. It is worthy to mention that, vitamin B complex consist from B2 (riboflavin), B3 (Aneurine hyrochloride) and B4 (nicotinamide). Triton $\mathrm{B}$ as a wetting agent was added at $0.1 \%$ for all spraying treatments. All trees were sprayed till run off $(15 \mathrm{~L} /$ tree), untreated trees was sprayed with tap water.

The results of the orchard soil analyses (according to Wilde et al 1985) are given in Table (1).

Samples of twenty leaves from the middle part of the shoots (According to Chuntonaparb and Cummings, 1981) were selected at random from each replicate (2nd week of July) to measure their area (cm.2) (According to Ahmed \& Morsy, 2001) and to determine their content of $\mathrm{N}, \mathrm{P} . \mathrm{K}$ and $\mathrm{Mg}$ (According to Wilde et al 1985) on dry weight basis.

Yield expressed in weight $(\mathrm{kg})$ and number of fruits per tree was recorded at harvest (last week of May and June).

Samples consisting of twenty fruits were randomly taken at harvest time from each replicate for determining average fruit weight $(\mathrm{g})$, fruit diameter, total soluble solids $\%$, total and reducing sugar $\%$ and total acidity \% (expressed as g malic acid per 100g pulp) (A.O.A.C., 1985). All the obtained data were tabulated and statistically analyzed according to Gomes and Gomes (1984). The differences among various treatment means were tested by New L. S. D parameter.

Table 1. Some characteristics of the soil at the trial location particle size distribution

\begin{tabular}{|c|c|}
\hline Sand $\%$ & 85.0 \\
\hline Silt $\%$ & 13.2 \\
\hline Clay $\%$ & 1.80 \\
\hline Texture grade & Sandy \\
\hline PH $(1: 2.5$ extract $)$ & 7.55 \\
\hline $\begin{array}{l}\text { EC (1:2.5 extract) (mmhos/ } \\
\left.\mathrm{cm} / 25^{\circ} \mathrm{C}\right)\end{array}$ & 0.69 \\
\hline Total $\mathrm{Ca} \mathrm{Co}_{3} \%$ & 5.2 \\
\hline O. $\mathrm{M} \%$ & 0.71 \\
\hline Total N & 0.036 \\
\hline Available P & 3.15 \\
\hline $\begin{array}{l}\text { Available K (ammonium ace- } \\
\text { tate, p.p.m) }\end{array}$ & 189.3 \\
\hline Available $\mathrm{Mg}^{++}$(p.p.m.). & 1.72 \\
\hline \multicolumn{2}{|c|}{ DTPA extractable micronutrients (p.p.m) } \\
\hline $\mathrm{Fe}$ & 2.22 \\
\hline $\mathrm{Mn}$ & 3.30 \\
\hline $\mathrm{Cu}$ & 1.1 \\
\hline $\mathrm{Zn}$ & 1.6 \\
\hline
\end{tabular}

\section{RESULTS AND DISCUSSION}

\section{1- Effect of spraying some nutrients on the leaf are}

It is clear from the data in Table (2) that folair application of magnesium sulphate at 0.50 to $3.0 \%$, boric acid at 0.20 to $1.0 \%$, ascorbic acid at 250 to 1000 p. p. $\mathrm{m}$ and vitamin B complex at 100 to 400 p. p. $m$ either singly or in combination significantly stimulated the leaf area compared to unspraying trees. The great promotion was occurred on trees received 
magnesium sulphate, boric acid, ascorbic acid and vitamin B complex in descending order. The promotion was associated with raising concentration of each material. Combined application of all materials was preferable in improving the leaf area than single application of each compound. The maximum leaf area in both seasons (26.30 and $24.80 \mathrm{~cm} 2)$ was recorded on the trees sprayed four times with a mixture containing all substances at the medium concentrations. Meanwhile, untreated trees produced the smaller leaves (20.1 and $19.3 \mathrm{~cm} 2$ in both seasons). These results were true in both seasons. The beneficial of $\mathrm{Mg}, \mathrm{B}$, ascorbic acid and B-Vitamins on the biosynthesis and movement of organic foods and natural hormones as well as the uptake of nutrients could explain the present results (Samiullah et al 1988 and Nijjar, 1995).

These results are in agreement with obtained by Ahmed and Morsy (2001) who worked on Mg, Abd EL-Aziz (1994) and Ahmed et al (1997b) who worked on Boron.

Ahmed et al (1997a) and Khiamy (1999) who worked on ascorbic acid and Morsy and EL-Bana (2000) who worked on vitamins B.

\section{2- Effect of spraying some nutrients on yield characteristics}

It is evident from the data in Table (2) that yield expressed in weight and number of fruits per tree was positively affected by spraying Canino apricot trees with magnesium sulphate, Boric acid, ascorbic acid and vitamin B complex either singly or at the medium concentrations compared to unspraying. There was a gradual promotion on the yield with raising concentration of each compound.
Significant differences on the yield were observed between all concentrations and various compounds except between the medium and the higher concentrations. In ascending order, foliar application of vitamin B complex, ascorbic acid, boric acid and magnesium sulphate was very effective for promoting the yield expressed in weight and number of fruits per tree. Using all compounds at the medium concentrations was followed by obtaining the maximum tree yield (55.5 and $52.9 \mathrm{~kg}$ in both seasons, respectively). The minimum yield (17.7 and $17.6 \mathrm{~kg}$ in both seasons) was recorded in untreated trees. These results were true in both the two experimental seasons. The stimulation on growth and nutritional status of the trees surely reflected on improving the yield. Similar results were obtained by Guo \& Xu (1998) and Ahmed \& Morsy (2001) who worked on $\mathrm{Mg}$ Abd-EL-Aziz (1994) and Ahmed et al (1997b) who worked on Boric acid, Ahmed et al (1997b) and Ahmed et al (1998 b) who worked on ascorbic acid and NomierSaffaa (2000) who worked on vitamins B.

\section{3- Effect of spraying some nutrients on Leaf mineral content $(N, P, K$ and Mg)}

Data in Tables (3) clearly show that foliar application of magnesium sulphate at 0.5 to $3.0 \%$, boric acid at 0.20 to $1.0 \%$, ascorbic acid at 250 to 1000 p.p. m, vitamin B complex at 100 to 400 p.p.m and all compounds at the medium concentrations significantly raised percentage of $\mathrm{N}$, $\mathrm{p}, \mathrm{k}$ and $\mathrm{Mg}$ in the leaves compared to unspraying. The promotion was associated with increasing the applied concentrations. 
Table 3. Effect of magnesium sulphate, boric acid, ascorbic acid and Vitamin B Complex on leaf minerals content (\%) of "Canino" apricot trees during 2004 and 2005 seasons.

\begin{tabular}{|c|c|c|c|c|c|c|c|c|}
\hline \multirow{2}{*}{ Treatment } & \multicolumn{2}{|c|}{$\mathrm{N} \%$} & \multicolumn{2}{|c|}{$\mathrm{P} \%$} & \multicolumn{2}{|c|}{$\mathrm{K} \%$} & \multicolumn{2}{|c|}{$\mathrm{Mg} \%$} \\
\hline & 2004 & 2005 & 2004 & 2005 & 2004 & 2005 & 2004 & 2005 \\
\hline Control & 1.01 & 1.18 & 0.18 & 0.20 & 1.02 & 1.06 & 0.26 & 0.27 \\
\hline $\begin{array}{l}\text { Magnesium sul- } \\
\text { phate at } 0.5 \%\end{array}$ & 1.47 & 1.55 & 0.33 & 0.37 & 1.36 & 1.43 & 0.49 & 0.43 \\
\hline $\begin{array}{l}\text { Magnesium sul- } \\
\text { phate at } 1.0 \%\end{array}$ & 1.53 & 1.61 & 0.36 & 0.39 & 1.40 & 1.48 & 0.52 & 0.45 \\
\hline $\begin{array}{l}\text { Magnesium sul- } \\
\text { phate at } 3.0 \%\end{array}$ & 1.54 & 1.62 & 0.37 & 0.40 & 1.41 & 1.49 & 0.53 & 0.46 \\
\hline $\begin{array}{l}\text { Boric acid at } \\
0.20 \%\end{array}$ & 1.35 & 1.45 & 0.28 & 0.32 & 1.24 & 1.33 & 0.41 & 0.39 \\
\hline Boric acid at $0.5 \%$ & 1.40 & 1.50 & 0.30 & 0.34 & 1.28 & 1.38 & 0.45 & 0.41 \\
\hline Boric acid at $1.0 \%$ & 1.40 & 1.51 & 0.31 & 0.35 & 1.32 & 1.39 & 0.46 & 0.42 \\
\hline $\begin{array}{l}\text { Ascorbic acid at } \\
250 \mathrm{ppm}\end{array}$ & 1.22 & 1.34 & 0.23 & 0.26 & 1.16 & 1.22 & 0.34 & 0.36 \\
\hline $\begin{array}{l}\text { Ascorbic acid at } \\
500 \text { P.P.m }\end{array}$ & 1.28 & 1.39 & 0.25 & 0.28 & 1.20 & 1.27 & 0.37 & 0.39 \\
\hline $\begin{array}{l}\text { Ascorbic acid at } \\
1000 \mathrm{ppm}\end{array}$ & 1.30 & 1.40 & 0.26 & 0.29 & 1.21 & 1.28 & 0.38 & 0.40 \\
\hline $\begin{array}{l}\text { Vitamin } B \text { com- } \\
\text { plex at } 100 \mathrm{ppm}\end{array}$ & 1.08 & 1.23 & 0.20 & 0.22 & 1.07 & 1.10 & 0.28 & 0.30 \\
\hline $\begin{array}{l}\text { Vitamin B com- } \\
\text { plex at } 200 \text { P.P.m }\end{array}$ & 1.15 & 1.28 & 6.23 & 6.23 & 1.11 & 1.16 & 0.31 & 0.34 \\
\hline $\begin{array}{l}\text { Vitamin B com- } \\
\text { plex at } 400 \mathrm{ppm}\end{array}$ & 1.16 & 1.29 & 0.24 & 0.24 & 1.12 & 1.17 & 0.32 & 0.35 \\
\hline $\begin{array}{l}\text { Combined treat- } \\
\text { ments }\end{array}$ & 1.59 & 1.68 & 0.40 & 0.42 & 1.45 & 1.56 & 0.56 & 0.50 \\
\hline New L.S.D at $5 \%$ & 0.05 & 0.04 & 0.02 & 0.02 & 0.03 & 0.04 & 0.02 & 0.02 \\
\hline
\end{tabular}

- Magnesium sulphate at $1.0 \%$, Boric acid at $0.5 \%$, Ascorbic acid at 500ppm. and Vitamin B complex at $200 \mathrm{ppm}$ 
Arab Univ. J. Agric. Sci., 14(1), 2006 
Insignificant increase on these nutrients was observed among the medium and higher concentration of each material. Treating Canino apricot trees with vitamins B complex, ascorbic acid, boric acid and magnesium sulphate, in ascending order was responsible for maximizing these nutrients in the leaves. The maximum values were detected on the trees received all compounds at the medium concentrations. The untreated trees produced the leaves with the lowest values. These results were true in both experimental seasons. The effect of these nutrients on enhancing the uptake of $\mathrm{N}, \mathrm{P}, \mathrm{K}$, and $\mathrm{Mg}$ could explain the present results. These results are in conordance with those obtained by Ahmed and by Morsy (2001) who worked on

$\mathrm{Mg}$ and B, Khaimy (1999) who worked on scorbic acid and Nomier-Saffaa (2000) who worked on vitamins B.

\section{4- Effect of spraying some nutrients on fruit quality}

Single or combined application of $\mathrm{Mg}, \mathrm{B}$, ascorbic acid and vitamin $\mathrm{B}$ complex was significantly effective in improving fruit quality in terms of increasing fruit weight, diameter or dimesions, pulp weight $\%$, total soluble solids \% and vitamin $\mathrm{C}$ as well as and reducing sugars and decreasing total acidity $\%$ and seed weight $\%$ compared to non application. The beneficial of these compounds in improving fruit quality could be arranged as follows in descending order $\mathrm{Mg}, \mathrm{B}$, ascorbic acid and vitamin B complex. Increasing concentrations was followed by a gradual promotion on fruit quality. Insignificant promotion on fruit quality was detected between the medium and higher concentrations.
The best results with regard to fruit quality were obtained due to spraying $\mathrm{Mg}, \mathrm{B}$, Ascorbic acid and vitamin B complex at the medium concentrations. The untreated trees failed to produce fruits with the higher quality. Similar trend was observed in both the two experimental seasons (Tables $2 \& 4$ ). The improvement occurred in the fruit quality due to supplying the trees via leaves with $\mathrm{Mg}, \mathrm{B}$, ascorbic acid and vitamin B complex could be attributed to their effect on enhancing the biosynthesis and translocation of carbohydrates and advancing fruit maturity (Nijjar, 1995). These results were supported by the results of Ahmed and Morsy (2001) who worked on $\mathrm{Mg}$ and B, Ahmed et al (1998a) and (1998b) who worked on ascorbic acid and Farag (1996) and Nomier-Safaa (2000), who worked on vitamin B complex. According to the aforementioned enclosed data, spraying $1.0 \%$ magnesium sulphate, $0.5 \%$ boric acid, $500 \mathrm{ppm}$ ascorbic acid and 200 ppm vitamin B complex four times caused great beneficial in improving growth and productivity of Canino apricot trees.

\section{REFERENCES}

Abd-EL Aziz, F.H. (1994). Productivity of Anna apple trees (Malus domestica L.) in relation to foliar spraying of boron. Minia J. Agric. Res \& Dev. 16(4):13651376.

Ahmed, F.F. and M.H. Morsy (2001). Response of "Canino" apricot trees grown in the new reclaimed land to application of some nutrients and ascorbic acid. The fifth Arabian Hort. Conf. Ismailia, Egypt, pp. 27-34.

Ahmed, F.F.; M.A. El-Sayed; A.H. Ali and F.M. El-Morsy (1997a). Physiologi- 
cal studies on the effect of ascorbic and citric acids in combined with some micronutrients on Red Roomy grapevines. Proc. $1^{\text {st }}$ Sc: Conf. of Agric. Sci., Fac. of Agric., Assiut Univ., 1: 99- 105.

Ahmed, F.F.; M.A. Ragab; A.A. Gobara and A.E.M. Mansour (1997b). Efficiency of spraying boron, zinc, potassium and sulphur as affected with application of urea for "Anna" apple trees (Malus domestica L.). Egypt. J. Hort. 24(1): 75-90.

Ahmed, F.F.; M.A. Ragab and A.E.M. Mansour (1998a). Effect of ascorbine and citrine on some mango cultivars. Egypt J. Hort. 25(1):15-25.

Ahmed, F.F.; A.M. Akl; A.A. Gobara and A.E.M. Mansour (1998b). Yield and quality of "Canino" apricot trees in response to foliar application of ascorbine and citrine fertilizers. Egypt J. Hort. 25(2): 203-208.

A.O.A.C. (1985). Association of Official Agriculture Chemists. Official Methods of Analysis, pp. 490-510, Washington DC.U.S.A.

Chekan, A.S. (1988): Effects of chlorocholine chloride (CCC) and macro and microelements on the growth and productivity of young spur type apple trees. Referativnyi Zhurnal, 2: 55-65.

Chekan, A.S. (1989): The effect of annual and periodic (alternate year) application of macro and micronutrient fertilizers on the physiological state and productivity of apple trees. Referativnyi Zhurnal, 10:66-77.

Chuntonaparab, N. and G. Cummings (1981): seasonal trends in concentration of nitrogen, phosphorus, potassium, calcium and magnesium in leaf portions of apple, blueberry, grape and peach. $\boldsymbol{J} . \mathbf{A m}$. Soc. Hort. Sci. 105 (6): 933.

Farag, K.M. (1999). Use of urea, phe- nylalanine and thiamine and their combinations to accelerate anthocyanin development and their effect on the storage life of flame seedless grapes. Proc. First Egyptian Hungarian Hort. Conf., Kafr El-Sheikh, Egypt, 32: 525-534.

Gomes, K.A. and A.A. Gomes (1984). Statistical Procedures for Agricultural Research. 680 pp., John Wiley and Sons. New York.U.S.A.

Guo, M. and H. Xu (1998): Cultural techniques for high quality, high production and high profits in apricot orchards in the aird loess plateau. China Fruits, 4: 34-36.

Khiamy, A.O. (1999). Response of Red Roomy Grapevines (Vitis vinifera L.) to Some Antioxidant and BiofertilizerTreatments. p. 123. M.Sc. Thesis, Fac. Agric., Minia Univ., Egypt.

Kodendaramaiah, J. and P. GopalaRao (1985). Influence of B- vitamins on stomatal index, frequency and diurnal rhythms in stomatal opening in Cyamposis tetragonolaba L. Taub. J. Bio. Res. 5: 68-73.

Mirabdulbaghi, M. (1996). Influence of zinc and boron on nutritional contents, yield and fruit quality of Golden Delicious apple and pear. Seed and Plant 12(3):16-23.

Morsy, M.H. and A.A. El-Bana (2000). Effects of some vitamins (Antioxidants) on growth of mango transplants and development of leaf blight disease. $8^{\text {th }}$ Conf. Agric. Dev. Res. Fac. Agric., Ain Shams Univ., Annals Agric. Sci. Sp. Issue, 3: 1259-1272.

Nijjar, G.S. (1995). Nutrition of Fruit Trees, pp. 206-234. Raj Kumar for Kalyani Publishers, New Delhi.

Nomier-Saffa, A. (2000). Effect of some $\mathrm{GA}_{3}$, vitamins and active dry yeast treatments on vegetative of Thomposon seed- 
less grapevines. Zagazig. J. gric. Res. 27(5): 1267-1286.

Oertli, J.J. (1987). Exogenous application of vitamins as regulators for growth and development of plants, $\boldsymbol{Z}$ Pflanzernahr, Bodenk, 150: 375-391.

Orth, A.B.; A. Sfarra; E.J. Pell and M. Tien (1993). Assessine the involvement of free radicials in fungicide to xicity using $\mathrm{x}$-tocopheral analogs. Pesticide Biochemistry and Physiology. 18:177183.

Prusky, D. (1988). The use of antioxidants to delay the onest of anthracnnose and stem end decay in avocado fruits after harvest. Plant Disease. 33:372-381.

Samiullah, S.A.; M.M. Ansari and R.K. Afridi (1988). B-vitamins in relation to crop productivity. Ind. Rev. Life. Sci. 8: 51-74.

Wilde, S.A.; R.B. Corey; J.G. Lyer and G.K. Voigt (1985). Soil and Planl Analysis for Tree Culture $3^{\text {rd }} \mathrm{Ed}$. pp. 89100. Oxford IBLT Publishing Co., New Delhi.

Wojcik, P.; A. Mika and G. Cieslinski (1997). Effect of boron fertilization of apple trees (malus domestica Borkh) on yield and fruit quality. Acta Agrobotanica 50 (1/2): 111-124.

Yogaratnam, N. and D.W.P. Greenham (1982). The application of foliar sprays containing nitrogen, magnesium, zinc and boron to apricot trees-1- Effect on fruit set and cropping. J. Hort. Sci. 57(2):151158.

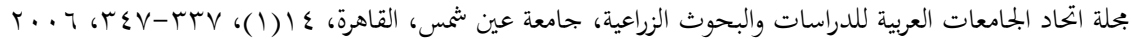

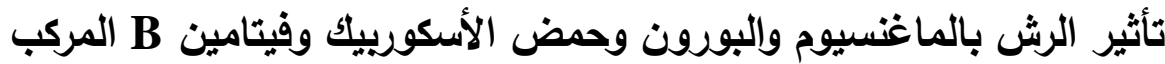 على المحصول وخصائص الجودة فى ثمار المشمش الكانينو}

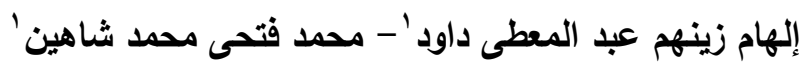

1- قسم بحوث الفاكهة - المركز القومى للبحوث - الدقى - القاهرة - مصر مئر

وكــان الاســتخدام الفـردى أو المشــرك

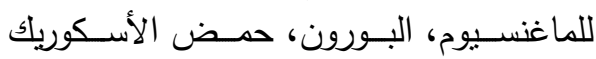

وفيتامين ب المركب مفيدا فى تحسين مساحة الاحنة

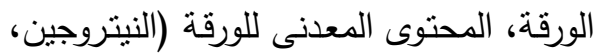

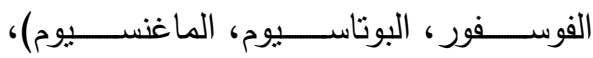

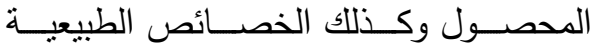

والكيميائية للثمار وذلك مقارنة بعدم الاستخدام

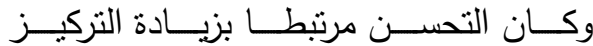

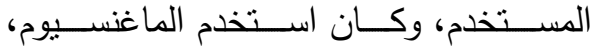

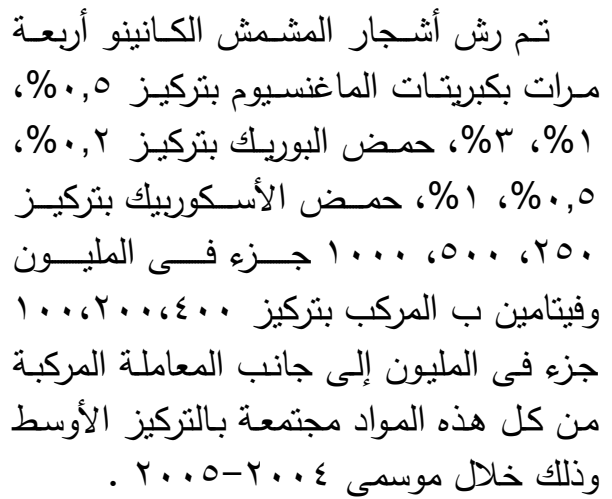

تم رش أنثـار المشـش الكـانينو أربعـة

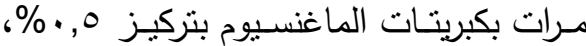

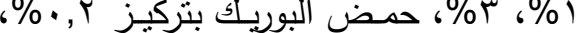

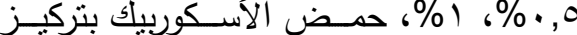

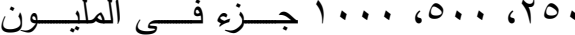

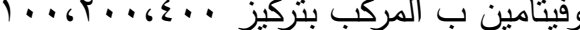

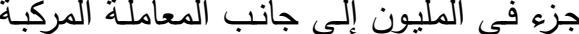

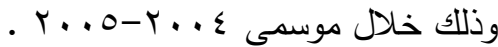


البـورون، حمـض الأسـكوربيك وفيتــامين ب الثمار فى أثجار المشمش الكانينو هـى التى

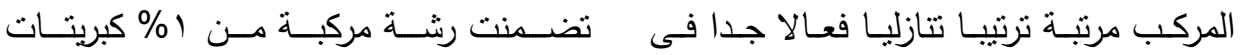

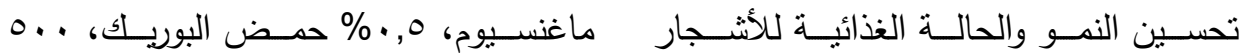

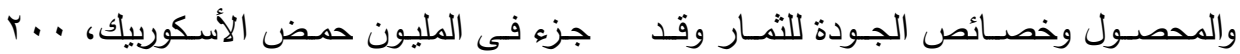

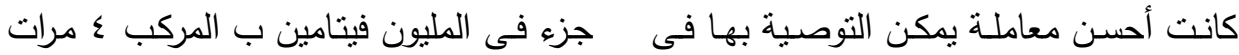

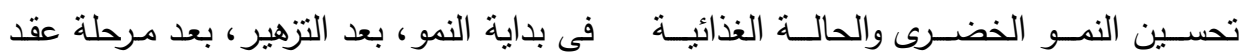

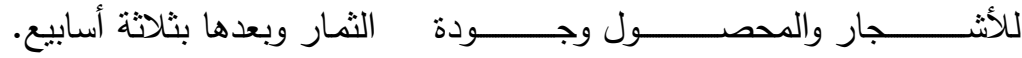

تحكيم: ا.د نظمى عبدالحميد عبد الغنى

ا.د بطرس نصـر بطرس عبدس عبد 